\title{
Investigation and disinfection of bacteria and fungi in sports fitness center
}

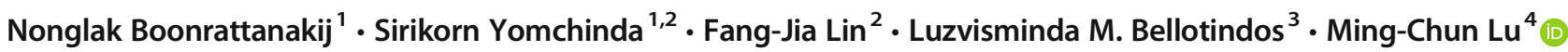

Received: 18 February 2021 / Accepted: 3 May 2021 / Published online: 20 May 2021

(C) The Author(s), under exclusive licence to Springer-Verlag GmbH Germany, part of Springer Nature 2021

\begin{abstract}
This study investigated the air quality improvement in terms of bacterial and fungal contamination in an exercise room of a fitness center under normal operating conditions. Environmental conditions including air conditioning, ventilation, moisture, $\mathrm{CO}_{2}$, particulate matters, and total number of users were also recorded. In addition, fungal and bacterial load were assessed and disinfection on sports equipment surface was also examined. Background bacteria and fungi densities in bioaerosols were in the range of $249 \pm 65$ to $812 \pm 111 \mathrm{CFU} / \mathrm{m}^{3}$ and $226 \pm 39$ to $837 \pm 838 \mathrm{CFU} / \mathrm{m}^{3}$ in the exercise room of the fitness center and $370 \pm 86$ to $953 \pm 136 \mathrm{CFU} / \mathrm{m}^{3}$ and $465 \pm 108$ to $1734 \pm 580 \mathrm{CFU} / \mathrm{m}^{3}$ in the outdoor air, respectively. Chlorine dioxide and weak acid hypochlorous water aerosols could remove both bacteria and fungi much better than water scrubbing. Contact time of $15 \mathrm{~min}$ was sufficient to control both bacteria and fungi to comply with the official air quality standards. User density and carbon dioxide deteriorated both bacteria and fungi disinfection performance whereas temperature was only statistically significant on fungi disinfection. Other factors including relative humidity, airflow velocity, and particulate matters did not have any statistically significant effect on microbial inactivation. Apart from bioaerosol disinfection, inactivation of microorganisms on surfaces of sports equipment was also conducted using chlorine dioxide, zinc oxide, weak acid hypochlorous water, and commercial disinfectant. The surfaces of bicycle handle, dumbbell, and sit-up bench were found to be contaminated with bacteria. Overall bacterial load was 390 to $3720 \mathrm{CFU} / \mathrm{cm}^{2}$ with Escherichia coli specifically 550 to $1080 \mathrm{CFU} / \mathrm{cm}^{2}$. Chlorine dioxide and zinc oxide were noticeably better than weak acid hypochlorous water and commercial disinfectant in terms of bacteria inactivation whereas all tested disinfectants had comparable effectiveness on E. coli disinfection. Targeted microorganisms on the sports equipment surface were sufficiently inactivated within 2 min after the application of disinfectant.
\end{abstract}

Keywords Fitness center · Bioaerosols $\cdot$ Disinfectant

Responsible Editor: Diane Purchase

Ming-Chun Lu

mmclu@nchu.edu.tw

1 Department of Environmental Engineering, Faculty of Engineering, King Mongkut's University of Technology Thonburi, Bangkok 10140, Thailand

2 Department of Environmental Resources Management, Chia Nan University of Pharmacy and Science, Tainan 71710, Taiwan

3 School of Engineering, University of San Carlos Talamban Campus, 6000 Cebu City, Philippines

4 Department of Environmental Engineering, National Chung Hsing University, Taichung 40227, Taiwan

\section{Introduction}

The current physical inactivity pandemic is one of the major leading risk factors for death worldwide. The World Health Organization (WHO) recommends at least $150 \mathrm{~min}$ of moderate-intensity physical activity throughout the week (Ramos et al. 2015; WHO 2018) for improving health benefits and overall well-being, such as walking, cycling, or sports. However, urban parks or indoor public spaces particularly in large cities usually have poor air quality due to traffic-related pollution. As a result, people who are living in urban areas prefer to work out in an indoor fitness center to avoid air pollution. Nonetheless, despite new recommendations of indoor air quality expanded to indoor public spaces, adoption has been slow. It largely depends on building construction, building materials, and type of ventilation together with 
environmental factors such as natural ventilation, humidity, and temperature (Saini et al. 2020). In addition, number of users and fitness activities also play an important role in the air quality inside the fitness center.

Bacteria and fungi can pose significant risk to human health under fitness center environments. The main source of bacteria present on the surface of fitness facilities is people who come to exercise (Ramos et al. 2014). Dalman et al. (2019) found $38.2 \%$ of the environmental surfaces in 16 fitness facilities in Northeast Ohio in the USA were contaminated with Staphylococcus aureus, a common gram-positive bacterium species found in the nose and throat of humans. On the other hand, most fungal sources are located outdoors, e.g., soil, plants, and water bodies. However, the spores can readily penetrate indoor environments by means of human transport and ventilation systems.

The Environmental Protection Administration (EPA) of Taiwan has stated that, for indoor public spaces, the bacteria concentration should be not higher than $1500 \mathrm{CFU} / \mathrm{m}^{3}$, while the fungi concentration should not exceed $1000 \mathrm{CFU} / \mathrm{m}^{3}$ (EPA Taiwan 2014). Unfortunately, Taiwan lies in a subtropical zone where the climate is generally warm and humid all year round. This type of climate is highly conducive to the breeding and spreading of bioaerosols (Tsai and Liu 2009). Moreover, recent spread of COVID-19 worldwide shows that drinking water disinfection (Garcia-Avila et al. 2021) and indoor air purification are extremely important and necessary.

Various types of chemical disinfectants can be used against microorganisms including glutaraldehyde, formaldehyde, and chlorhexidine (Mcdonnell and Russell 1999). However, the use of such disinfectants - though effective in industrial setting - may be harmful when used in public application. Thus, the toxic, corrosive, and volatile properties must be thoroughly evaluated.

Chlorine dioxide $\left(\mathrm{ClO}_{2}\right)$ can be used as an oxidizing agent or disinfectant. It is a very powerful oxidizer that effectively eliminates pathogenic microorganisms including fungi, bacteria, and viruses. As a disinfectant and pesticide, it is mainly applied in a liquid form (Lenntech B.V. 2020). Weak acid hypochlorous water (WAHW), a most widely used disinfectant with good antimicrobial activity, can also be used as well (Chen et al. 2012; Nguyen et al. 2021). WAHW is environmentally friendly since it is unaffected by water hardness (Rutala and Weber 1997). Likewise, antibacterial activity of zinc oxide $(\mathrm{ZnO})$ nano-powders has received significant interest worldwide (Sirelkhatim et al. 2015; Dimapilis et al. 2018).

In this study, $\mathrm{ClO}_{2}$ and WAHW, which are applicable for air purification, were used to determine their microbicidal disinfection efficiency on bioaerosols present in the fitness center. Water was also used to serve as a control for scrubbing effect. The evaluation covers indoor air quality and sports equipment. The air inside the studied rooms of the fitness center was disinfected in a patron concentration manner, i.e., 0, 5, and 10 patrons. Environmental factors including temperature, relative humidity, and airflow velocity were measured and maintained steadily. In all aerosol disinfection scenarios, the solution was applied using EP606 aerosol devices (GAO-SHUO Corporation, Taiwan) for $60 \mathrm{~min}$ after the exercise period. Bacteria and fungi remaining in the aerosols were periodically monitored and compared. For sports equipment study, three equipment with different surface characteristics were tested including bicycle handle with soft and foam-like surface, dumbbell with rough steel surface, and sit-up bench with smooth leather surface. Disinfectant solution of either $\mathrm{ClO}_{2}$, WAHW, $\mathrm{ZnO}$, or commercial disinfectant was used to clean all contact surfaces of each equipment after each of the exercise session. Total bacteria and Escherichia coli (E. coli) remaining on the surface were periodically monitored and compared. E. coli, a common gram-negative bacterium, was chosen as a representative species since several researchers have already investigated the gram-positive bacterium as a metric of microbial contamination in a fitness center and gymnasium (Ryan et al. 2011; Markley et al. 2012; Mukherjee et al. 2016; Dalman et al. 2019). The outcomes from this study will fulfill the overall perspective of bacterial contamination on sports equipment.

\section{Materials and methods}

This study was conducted in the fitness center at Chia-Nan University of Pharmacy and Science in Taiwan. This study consists of two parts: (1) determination of bacteria and fungi existence in the indoor air and (2) determination of bacteria and $E$. coli existence on the surface of sports equipment, both before and after treatment with various disinfectants. All experimental scenarios were replicated to ensure data reliability. The details of the experimental procedure are described in the sections below.

\section{Study area}

Microbial sampling was undertaken in a $332 \mathrm{~m}^{3}$ bicycle room in a fitness center of Chia Nan University of Pharmacy and Science in Tainan, Taiwan. Sampling was taken at six locations, including five locations inside and one location outside the bicycle room as shown in Fig. 1.

\section{Disinfection method}

Several disinfectants including $\mathrm{ClO}_{2}$, WAHW, $\mathrm{ZnO}(5.4 \mathrm{wt} \%$ nanopowder aqueous solution with APS $<20 \mathrm{~nm}$, LIWEI Nano Tech Co., Ltd.), and commercial disinfectant with cetrimide and chlorhexidine digluconate as the active 


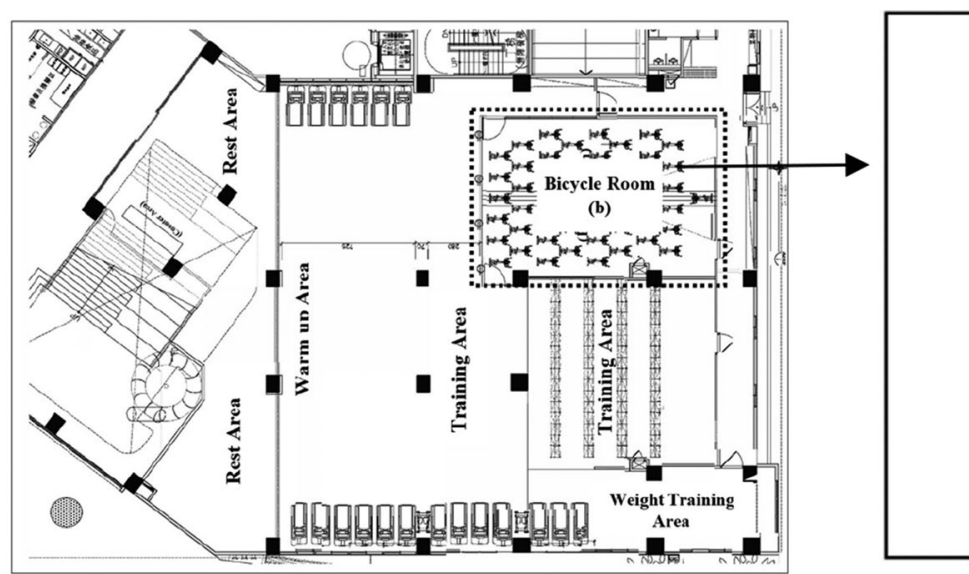

(a)

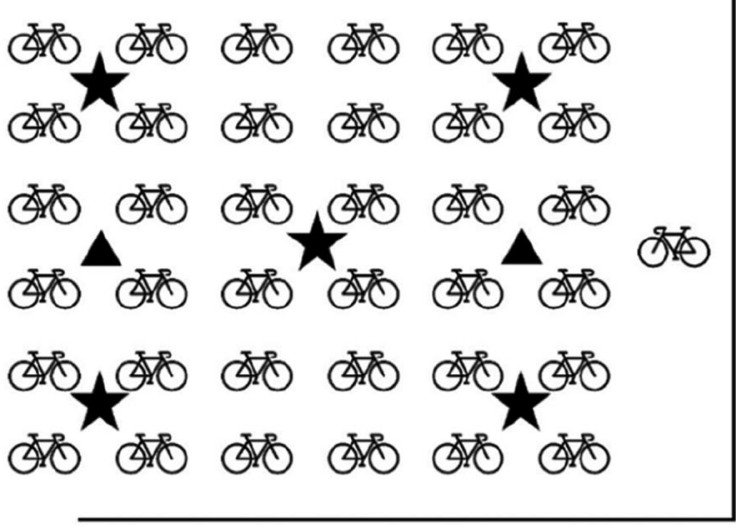

(b)

Fig. 1 Floor plans of sampling areas. (a) Total area. (b) Bicycle room. ( $(9=$ outdoor sampling location $\downarrow=$ sample location; $\boldsymbol{\Delta}=$ disinfecting aerosol applying location)

ingredients (Savlon, ITC Limited) were applied in this study in order to disinfect or remove the microorganisms. For bioaerosol study, $\mathrm{ClO}_{2}$ solution and WAHW were used. Control experiments with water (no disinfecting chemical) were conducted to investigate the effect of physical scrubbing. As described above, the bicycle room volume is $332 \mathrm{~m}^{3}$. To satisfy the 8-h time-weighted average (TWA) maximum exposure limit of $0.3 \mathrm{mg} / \mathrm{m}^{3}$ for $\mathrm{ClO}_{2}$ (OSHA 2020), $\mathrm{ClO}_{2}$ disinfection in the bicycle room was performed using $400 \mathrm{~mL}$ $\mathrm{ClO}_{2}$ solutions (at $250 \mathrm{mg} / \mathrm{L}$ ). No maximum exposure limit is prescribed for WAHW disinfection. Nonetheless, in order to control the amount of aerosols being introduced into the studied boundary, the rates of WAHW (at $250 \mathrm{mg} / \mathrm{L}$ ) and water aerosolization were similar to those of $\mathrm{ClO}_{2}$. The two EP606 aerosol devices (GAO-SHUO Corporation, Taiwan) placed at two different locations in the bicycle room were switched on just after the termination of all exercise activities, and all users had left the room and continued for $60 \mathrm{~min}$.

For bacterial inactivation on the surface of sports equipment, $\mathrm{ClO}_{2}$, WAHW, $\mathrm{ZnO}$, and commercial disinfectant (Savlon, ITC Limited) at the concentration of 50, 50, 400, and $400 \mathrm{mg} / \mathrm{L}$ were used. The surface of the sports equipment was wiped thoroughly by the sterilized cloth dampened with disinfectant mixture.

\section{Sample collection}

Air samples were collected in accordance with the NIEA (National Institute of Environmental Analysis) guidelines specified by the Taiwan Environmental Protection Administration (TEPA) (Taiwan EPA 2016a, b). On each sampling day, indoor air samples were collected before and after the exercise session (either with 5 and 10 users) at 15 and $60 \mathrm{~min}$. The samples were collected using a MAS-100 Eco Microbial Air Sampler (Merck, Germany, @ 200 L/min) in petri dishes filled with tryptic soy agar (TSA) plates and malt extract agar (MEA) for bacteria and fungi enumeration, respectively. Air flow velocity, temperature, relative humidity, and particulate matters (PM10, PM7, PM2.5, and PM1) were also measured.

Collection of microbial samples on sports equipment, i.e., bicycle handle, dumbbell, and sit-up bench, was performed before the cleaning and after cleaning at 2, 5, 10, and $30 \mathrm{~min}$. Five random swabs were performed for each sports equipment. Each swab was done on $1-\mathrm{cm}^{2}$ surface of the sports equipment using a sterilized cotton bud soaked with basal medium. The swabbed cotton buds were then further processed for microbial enumeration. To determine the amount of viable microorganisms, the samples were cultivated on Petri dishes with plate count agar (PCA) plates for bacteria and chromocult coliform agar plates for E. coli.

\section{Analytical methods}

\section{Measurement of environmental factors}

The temperature, relative humidity, airflow velocity, and carbon dioxide concentration were evaluated by The VelociCalc ${ }^{\circledR}$ Multi-Function Ventilation Meter 9565 (TSI Inc., USA). Light meter pocket (Lutron Electronic, LX-103) was used to measure the illumination in the room. Particulate matter was measured by handheld particle mass counter (AEROCET 531, Met One Instruments Inc., USA).

\section{Measurement of disinfectants concentration}

The concentration of chlorine dioxide and hypochlorous acid was determined by using light absorbance measurement by waterproof portable colorimeter (OAKTON Instrument, USA). 


\section{Microbiological analysis}

For the bioaerosol bacteria, the TSA plates were incubated at the temperature of $30 \pm 1{ }^{\circ} \mathrm{C}$ for $48 \pm 2 \mathrm{~h}$. Meanwhile, the MEA plates were incubated at $25 \pm 1{ }^{\circ} \mathrm{C}$ for $4 \pm 1$ day for measurement of bioaerosols fungi. The bacteria and fungi concentrations were then evaluated by counting the colonies formed on the respective agar surfaces.

For microorganism numeration from sports equipment, the initial sample was diluted with Butterfield's phosphatebuffered dilution water (PBS) at the dilution of 1:10, 1:100, $1: 1000$, and 1:10,000. After that, appropriate amount of the diluted sampled was dropped into the plate count agar (PCA) or chromocult coliform agar in the Petri dishes and then swirled the plate to homogeneously mix the sample and culture medium together. Allow the mixture to solidify and then turn the culture dish upside down. Then, the PCA plates were incubated at a temperature of $35 \pm 1{ }^{\circ} \mathrm{C}$ for $48 \pm 2 \mathrm{~h}$. Meanwhile, the chromocult coliform agar plates were incubated at $35 \pm 1{ }^{\circ} \mathrm{C}$ for $48 \pm 2 \mathrm{~h}$ for the $E$. coli cultivation. Count the number of colonies on the culture plate and calculate total microbial count in terms of CFU/mL (Jaemsri and Rujak 2017).

\section{Statistical analysis}

The experimental data were analyzed statistically using a commercial SPSS software (IBM SPSS Statistics 22.0). The correlations of the bioaerosols disinfection effectiveness and environmental factors (i.e., the temperature, relative humidity, airflow velocity, carbon dioxide concentration, and particulate matters) were examined by means of Pearson's correlation analysis $(p<0.05)$.

\section{Results and discussion}

\section{Bioaerosols in indoor air}

\section{Initial concentration of bioaerosols}

The initial concentrations of bacteria and fungi before the disinfection treatment are shown in Table 1. Average temperature, relative humidity, airflow velocity, carbon dioxide, PM1, PM2.5, PM7, and PM10 during the experimental periods were 18.9 to $24.9{ }^{\circ} \mathrm{C}, 62.0$ to $80.6 \%, 0.3$ to $1.2 \mathrm{~m} / \mathrm{min}$, 398 to $1298 \mathrm{ppm}, 0$ to $1.12 \mathrm{mg} / \mathrm{m}^{3}, 0.001$ to $1.170 \mathrm{mg} / \mathrm{m}^{3}$, 0.002 to $1.175 \mathrm{mg} / \mathrm{m}^{3}$, and 0.002 to $1.179 \mathrm{mg} / \mathrm{m}^{3}$, respectively. The magnitude of these environmental factors represents the typical conditions of the indoor air in the fitness center. It is necessary to note that the experiments were conducted at existing conditions and different times; hence, the initial concentrations of bacteria and fungi in each experiment were different. Therefore, the determination of whether an indoor environment is polluted or not is often based on a comparison of bioaerosol concentration in the indoor air with that of outdoors (Zhu et al. 2003). It can be seen that the indoor air tended to contain less bacteria and fungi than the outdoor air (outside the sport center); nonetheless, there was no specific correlation. This is possibly due to the bioaerosol filtration effect via air conditioning system of the fitness center and the activities happened prior to the tested session.

\section{Effect of environmental factors on bioaerosols distribution}

Table 2 shows the correlations between the bacteria and fungi colony counts and the environmental factors after the disinfection treatment process. Significant positive correlations were found between the effectiveness of bacteria disinfection and the effectiveness of fungi disinfection $(\mathrm{r}=$ $0.610, p<0.01)$. By contrast, significant negative correlations were obtained between the effectiveness of bacteria disinfection and the number of users $(r=-0.584, p<0.05)$ and carbon dioxide concentration $(\mathrm{r}=-0.581, \mathrm{p}<0.05)$. Significant negative correlations also existed between the effectiveness of fungi disinfection and the number of users $(\mathrm{r}=-0.690, p<0.01)$, temperature $(\mathrm{r}=-0.517, \mathrm{p}<0.05)$, and carbon dioxide concentration $(r=-0.680, p<0.01)$. In other words, the effectiveness of bacteria disinfection increased along with the effectiveness of fungi disinfection but decreased with an increasing number of users and carbon dioxide concentration. Similarly, the effectiveness of fungi disinfection decreased with an increasing number of users, temperature, and carbon dioxide concentration. Carbon dioxide level highly correlated to the user density with the $p$ value of less than 0.01 which was expected because the major source of carbon dioxide in the fitness center was from human respiration. Other factors including relative humidity, airflow velocity, and particulate matters had no statistically significant impact on both bacteria and fungi inactivation. Nonetheless, it was found that air velocity and particulate matters (PM1, PM2.5, PM7, PM10) were related to one another at the 0.05 level. This should be primarily due to the particle filtration by air conditioning system. In addition, Table 2 also suggested that all particulate matters present in the air inside this fitness center are likely derived from the same source since all of them are highly correlated to one another at the significant level of 0.01 .

\section{Effectiveness of bioaerosols disinfection}

The effectiveness of bacteria and fungi disinfection by three different methods: $\mathrm{ClO}_{2}$, WAHW, and water were compared within treatment period of 15 and $60 \mathrm{~min}$ as shown in Figs. 2 and 3 , respectively. The results showed that all the methods had the ability to reduce bacteria and fungi present in the 
Table 1 Initial concentration of bacteria and fungi (mean $\pm \mathrm{SD}$ )

\begin{tabular}{|c|c|c|c|c|c|c|}
\hline & \multicolumn{3}{|l|}{ Indoor } & \multicolumn{3}{|l|}{ Outdoor } \\
\hline & $\mathrm{ClO}_{2}$ & WAHW & Water & $\mathrm{ClO}_{2}$ & WAHW & Water \\
\hline \multicolumn{7}{|c|}{ Initial concentration of bacteria $\left(\mathrm{CFU} / \mathrm{m}^{3}\right)$} \\
\hline 0 people & $401 \pm 179$ & $249 \pm 65$ & $308 \pm 231$ & $855 \pm 41$ & $370 \pm 86$ & $613 \pm 163$ \\
\hline 5 people & $761 \pm 169$ & $470 \pm 238$ & $433 \pm 172$ & $953 \pm 136$ & $616 \pm 203$ & $498 \pm 124$ \\
\hline 10 people & $715 \pm 153$ & $619 \pm 259$ & $812 \pm 111$ & $765 \pm 403$ & $684 \pm 591$ & $879 \pm 83$ \\
\hline \multicolumn{7}{|c|}{ Initial concentration of fungi $\left(\mathrm{CFU} / \mathrm{m}^{3}\right)$} \\
\hline 0 people & $226 \pm 39$ & $228 \pm 53$ & $618 \pm 499$ & $1203 \pm 603$ & $873 \pm 460$ & $1064 \pm 139$ \\
\hline 5 people & $837 \pm 838$ & $275 \pm 212$ & $307 \pm 16$ & $1734 \pm 580$ & $738 \pm 174$ & $908 \pm 706$ \\
\hline 10 people & $492 \pm 278$ & $255 \pm 133$ & $613 \pm 319$ & $1220 \pm 156$ & $465 \pm 108$ & $764 \pm 677$ \\
\hline
\end{tabular}

Remark: "N" $=2$ or 3 aerosols in the indoor air although water which served as a control had the lowest capability in both bacteria and fungi removals. Hence, it implies that the removal of bacteria and fungi in the presence of $\mathrm{ClO}_{2}$ and WAHW was mainly derived from chemical interaction rather than physical phenomenon. The inactivation potential decreased as the number of users increased. It is interesting to observe that fungi can be inactivated in all treatment scenarios at 15 min of contact time but $\mathrm{ClO}_{2}$ had the highest efficiency. However, the number of fungi noticeably rebounded in the WAHW and water scrubbing treatments at $60 \mathrm{~min}$. This regrowth behavior of fungi might be due to the ability of fungi to form spores to protect themselves from inactivation. Another factor might be due to an increase in relative humidity after prolonged aerosolization which could promote the enumeration of fungi (Rajasekar and Balasubramanian 2011). Figures 2 and 3 also illustrate that
$\mathrm{ClO}_{2}$ seemed to be a better fungicide whereas WAHW seemed to be a slightly better bactericide than $\mathrm{ClO}_{2}$ for long time exposure.

According to Ishihara et al. (2017), the hypochlorous acid in aqueous solution is unstable against ultraviolet (UV) light, sunshine, air contact, and elevated temperature $\left(\geq 25^{\circ} \mathrm{C}\right)$; hence, $\mathrm{ClO}_{2}$ seems to be a better choice for bioaerosol disinfection. As shown in Table 1, bacteria and fungi disinfection effectiveness were not related to treatment time; hence, disinfecting the fitness room for $15 \mathrm{~min}$ after usage is a more appropriate option that can reduce both treatment time and cost. Within the ranges obtained during the experimental period, other compositions in the room including temperature, relative humidity, air flow velocity, PM10, PM7, PM2.5, and PM1 had no statistically significant effect on bacteria and fungi disinfection.

Table 2 Correlations between disinfection effectiveness and environmental factors

\begin{tabular}{|c|c|c|c|c|c|c|c|c|c|c|c|}
\hline & $\begin{array}{l}\% \text { effective on } \\
\text { bacteria } \\
\text { disinfection }\end{array}$ & $\begin{array}{l}\% \text { effective on } \\
\text { fungi disinfection }\end{array}$ & $\begin{array}{l}\text { No. of } \\
\text { users }\end{array}$ & Time & Temp. & $\begin{array}{l}\text { Relative } \\
\text { humidity }\end{array}$ & $\begin{array}{l}\text { Airflow } \\
\text { velocity }\end{array}$ & $\begin{array}{l}\text { Carbon } \\
\text { dioxide }\end{array}$ & $\mathrm{PM}_{1}$ & $\mathrm{PM}_{2.5}$ & $\mathrm{PM}_{7}$ \\
\hline $\begin{array}{l}\% \text { effective on } \\
\text { fungi } \\
\text { disinfection }\end{array}$ & $0.610^{* *}$ & & & & & & & & & & \\
\hline No.of users & $-0.584^{*}$ & $-0.690 * *$ & & & & & & & & & \\
\hline Time & 0.114 & -0.302 & 0 & & & & & & & & \\
\hline Temp. & -0.258 & $-0.517 *$ & $0.564 *$ & -0.032 & & & & & & & \\
\hline Relative humidity & -0.026 & -0.209 & 0.319 & 0.141 & -0.138 & & & & & & \\
\hline Airflow velocity & -0.222 & -0.056 & 0.379 & 0.024 & 0.179 & 0.042 & & & & & \\
\hline Carbon dioxide & $-0.581 *$ & $-0.680 * *$ & $0.961 * *$ & 0.058 & 0.411 & $0.483 *$ & 0.32 & & & & \\
\hline $\mathrm{PM}_{1}$ & -0.198 & -0.249 & 0.39 & -0.016 & $0.477 *$ & 0.293 & $0.518^{*}$ & 0.383 & & & \\
\hline $\mathrm{PM}_{2.5}$ & -0.07 & -0.147 & 0.322 & -0.015 & 0.433 & 0.334 & $0.522 *$ & 0.314 & $0.986 * *$ & & \\
\hline $\mathrm{PM}_{7}$ & 0.023 & -0.072 & 0.267 & -0.012 & 0.396 & 0.359 & $0.512 *$ & 0.259 & $0.959 * *$ & $0.993 * *$ & \\
\hline $\mathrm{PM}_{10}$ & 0.023 & -0.077 & 0.273 & -0.007 & 0.395 & 0.364 & $0.510^{*}$ & 0.268 & $0.959 * *$ & $0.993 * *$ & $1.000 * *$ \\
\hline
\end{tabular}

**Correlation is significant at the 0.01 level (2-tailed)

*Correlation is significant at the 0.05 level (2-tailed) 


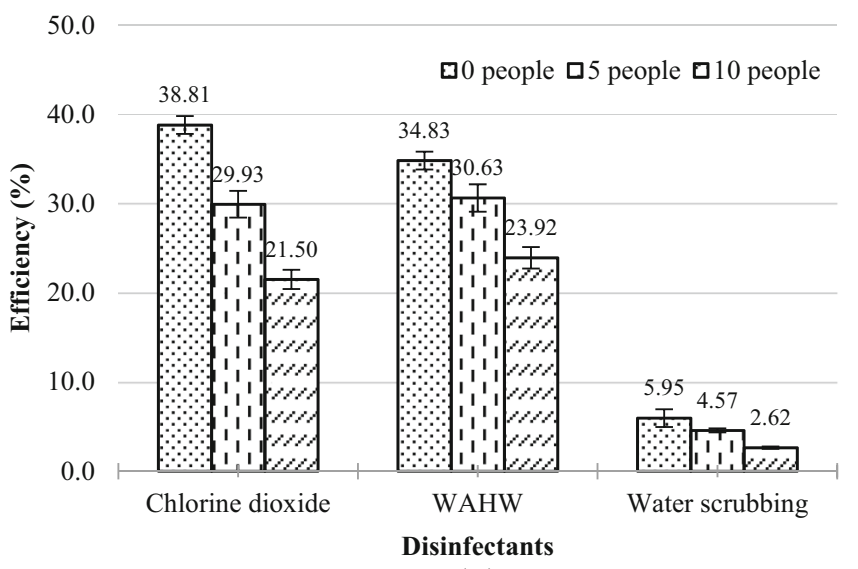

(a)

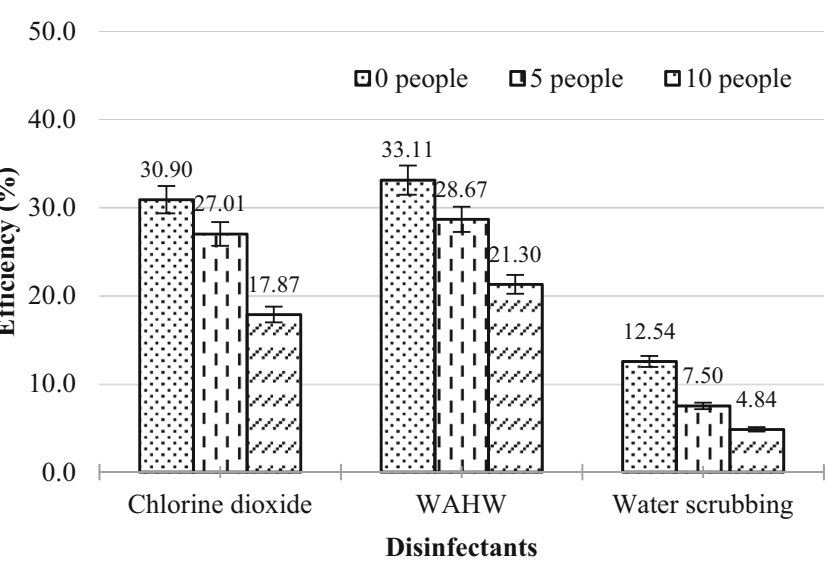

(b)

Fig. 2 Effectiveness of bacteria disinfection (a) after $15 \mathrm{~min}$ and (b) after $60 \min (N=2$ or 3$)$

The results from this study showed that the effectiveness both of bacteria and fungi disinfection decreased with an increasing number of users, time, temperature, and carbon dioxide concentration. It was found that $\mathrm{ClO}_{2}$ seemed to be the most appropriate selection for bacteria and fungi control in the bioaerosols under the studied conditions. This is because $\mathrm{ClO}_{2}$ is a very powerful oxidizer that effectively eliminates pathogenic microorganisms including fungi, bacteria, and viruses (Lenntech B.V. 2020). Findings from this study are in agreement with several other studies using $\mathrm{ClO}_{2}$ to control the amount of bioaerosols in indoor air including student cafeterias (Hsu et al. 2014), library (Hsu et al. 2015), and pet shop (Lu et al. 2018). These studies recommended that treatment with $\mathrm{ClO}_{2}$ is an efficient way of compliance with the Taiwan EPA guidelines for indoor air quality. Nonetheless, this study found that airflow velocity had no significant effect on both bacteria and fungi removal which contrasts with the observations from Hsu et al. (2014) and $\mathrm{Lu}$ et al. (2018) who found that a higher air velocity was helpful for spreading the disinfectants through indoor space as well as to enhance

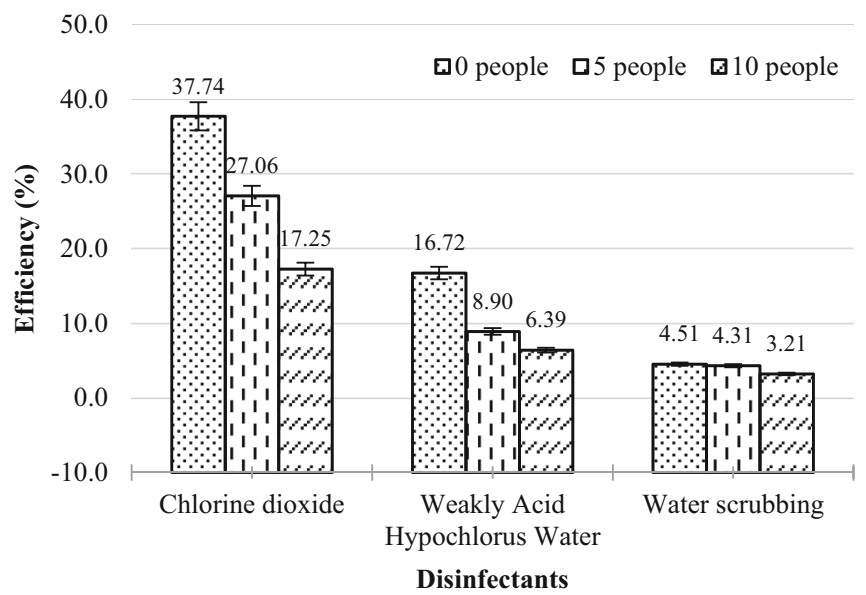

(a) disinfection efficiency accordingly. This might be because the minimum airflow rate of $0.3 \mathrm{~m} / \mathrm{min}$ detected in this study was already sufficient enough to thoroughly spread the disinfectant solution in the room space. The results confirmed that $\mathrm{ClO}_{2}$ disinfection could sufficiently suppress the numbers of bacteria and fungi present in the bioaerosols to comply with the Taiwan EPA guidelines for the indoor air quality.

\section{Bioaerosols on sports equipment}

\section{Initial concentration of microorganisms}

Table 3 shows the initial concentrations of bacteria and E. coli before cleaning the sports equipment. The initial concentrations of bacteria and $E$. coli were different among each experiment because it is based on the number of people who exercised with the specific equipment namely bicycle handle (rubber surface), dumbbell (rough steel surface), and sit-up bench (synthetic leather surface) in the fitness center prior to

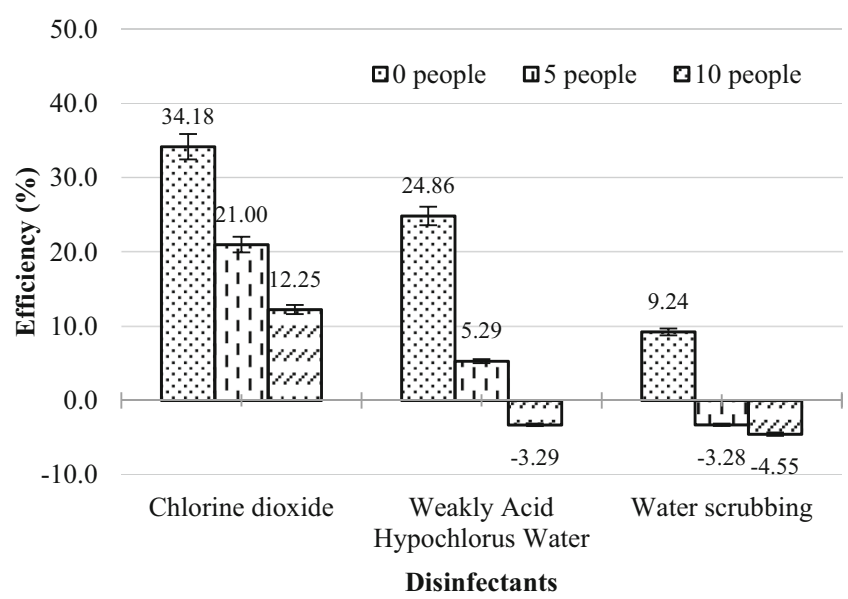

(b)

Fig. 3 Effectiveness of fungi disinfection (a) after 15 min and (b) after $60 \min (\mathrm{N}=2$ or 3 ) 
Table 3 Initial concentration of bacteria and $E$. coli on sports equipment, $N=2($ mean $\pm \mathrm{SD})$

\begin{tabular}{|c|c|c|c|c|}
\hline & $\mathrm{ClO}_{2}$ & WAHW & $\mathrm{ZnO}$ & Commercial disinfectant \\
\hline \multicolumn{5}{|c|}{ Initial concentration of bacteria $\left(\mathrm{CFU} / \mathrm{cm}^{2}\right)$} \\
\hline Bicycle handle & $756 \pm 278$ & $390 \pm 2$ & $3720 \pm 736$ & $1132 \pm 430$ \\
\hline Dumbbell & $684 \pm 232$ & $1070 \pm 144$ & $1596 \pm 418$ & $860 \pm 260$ \\
\hline Sit-up bench & $820 \pm 28$ & $816 \pm 210$ & $840 \pm 566$ & $1486 \pm 234$ \\
\hline \multicolumn{5}{|c|}{ Initial concentration of $E$. coli $\left(\mathrm{CFU} / \mathrm{cm}^{2}\right)$} \\
\hline Bicycle handle & $990 \pm 146$ & $1080 \pm 114$ & $628 \pm 266$ & $550 \pm 70$ \\
\hline Dumbbell & $786 \pm 50$ & $700 \pm 28$ & $732 \pm 118$ & $1002 \pm 224$ \\
\hline Sit-up bench & $866 \pm 94$ & $802 \pm 286$ & $960 \pm 170$ & $910 \pm 14$ \\
\hline
\end{tabular}

Remark: "N" = 2

the testing period. It is necessary to note that the experiments were conducted at existing conditions and at different times.

\section{Factors affecting microbial inactivation on sports equipment}

Table 4 shows the correlations between the bacteria and E. coli disinfection and the related factors. Significant positive correlations were found between the effectiveness of bacteria disinfection and the effectiveness of $E$. coli disinfection $(\mathrm{r}=$ $0.437, p<0.01)$ and types of equipment $(\mathrm{r}=0.446, \mathrm{p}<0.01)$. Significant positive correlations also existed between the effectiveness of $E$. coli disinfection and types of equipment $(\mathrm{r}=$ $0.396, \mathrm{p}<0.01)$. In other words, the effectiveness of bacteria and $E$. coli disinfection depends on the surface characteristics of sports equipment. Sports equipment selected in this study had different surface characteristics: (1) the handles of bicycle is soft with foam-like surface, (2) the dumbbell is steel and has a rough surface, and (3) the sit-up bench is covered with leather and has smooth surface. Other factors including time and types of the disinfectants had no statistically significant impact on both bacteria and $E$. coli inactivation.

\section{Effectiveness of bacteria and $E$. coli disinfection}

Figures 4 and 5 show the efficiency of the four disinfectants in reducing bacteria and $E$. coli present on the sports equipment surface after applying for 2, 5, 10, and $30 \mathrm{~min}$. The results show that all the disinfectants are highly effective in reducing bacteria and $E$. coli present on sports equipment (about 66.8-
$95.4 \%$ ) even within a short period of time after application (2 $\mathrm{min})$.

Figures 4(a) and 5(a) show that chlorine dioxide is highly effective in reducing bacteria and $E$. coli present on sports equipment (81.0-93.9\%). It can be seen that $\mathrm{ClO}_{2}$ could remove bacteria and $E$. coli immediately after 2 min of application. Therefore, users can use this equipment straightaway after disinfection without a long-waiting period. According to Cho et al. (2017), chlorine dioxide $\left(\mathrm{ClO}_{2}\right)$ has emerged as an alternative because it has better antimicrobial effectiveness with a higher solubility, shorter response time, and wider $\mathrm{pH}$ range. Moreover, the inactivation effectiveness of $\mathrm{ClO}_{2}$ on both bacteria and $E$. coli was not significantly affected by surface characteristic variation among the sports equipment. Hence, it can be used as a common disinfectant for all equipment in the fitness center. WAHW appeared to be less slightly effective in bacteria and E. coli inactivation than $\mathrm{ClO}_{2}$ as illustrated in Figs. 4(b) and 5(b). Required contact time for WAHW seemed to be 10 min which was much longer than those of $\mathrm{ClO}_{2}$. This observation is in agreement with the studies of Block and Rowan (2020) and Quan et al. (2017) who stated that hypochlorous acid required at least 10 min of contact time to be effective for antimicrobials.

Zinc oxide is highly effective in reducing bacteria for all of sports equipment as shown in Figs. 4(c) and 5(c). However, it is more effective in reducing $E$. coli on bicycle handle and situp bench than dumbbell. Comparing to $\mathrm{ClO}_{2}$ and WAHW, it was found that $\mathrm{ZnO}$ has a slightly better performance on bacteria and $E$. coli disinfection. Nonetheless, direct application

Table 4 Correlations between inactivation effectiveness and environmental factors on sports equipment

\begin{tabular}{llll}
\hline & $\begin{array}{l}\text { \% efficiency on } \\
\text { bacteria disinfection }\end{array}$ & $\begin{array}{l}\text { \% efficiency on } \\
\text { E. coli disinfection }\end{array}$ & $\begin{array}{c}\text { Types of } \\
\text { Equipment }\end{array}$ \\
\hline \% efficiency on E. coli disinfection & $0.437^{* * *}$ & & \\
Equipment & $0.446^{* *}$ & $0.396^{* *}$ & 0.000 \\
Disinfectant & 0.092 & 0.009 & 0.000 \\
Time & -0.097 & 0.040 & 0.000 \\
\hline
\end{tabular}

**Correlation is significant at the 0.01 level (2-tailed) 


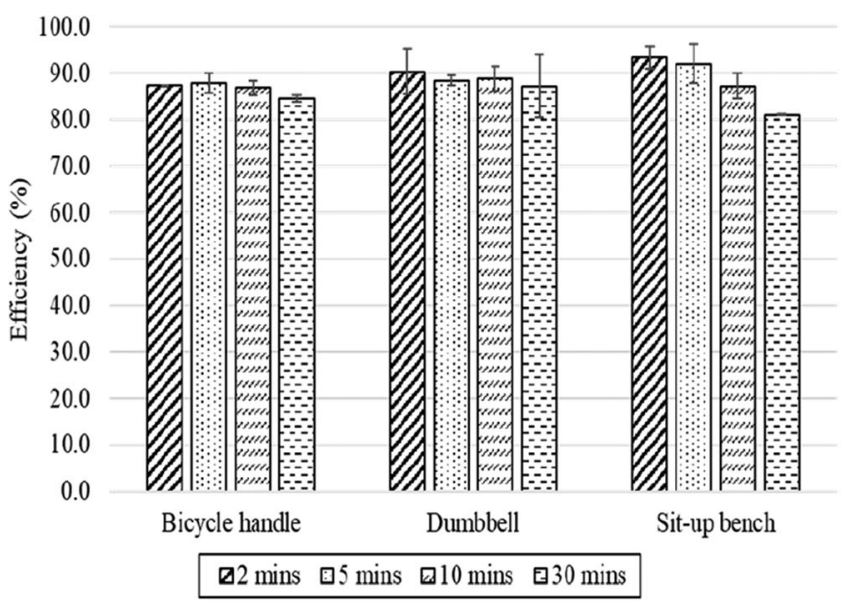

(a)

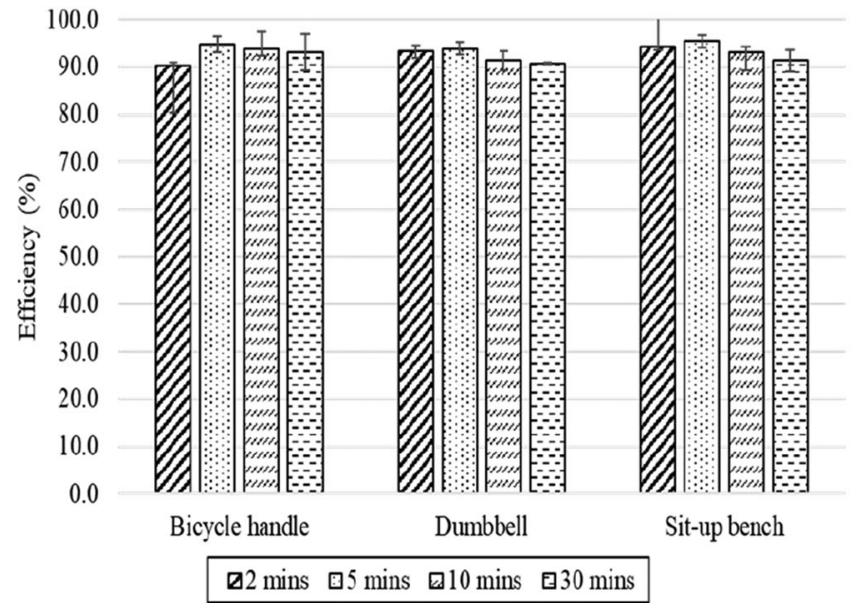

(c)

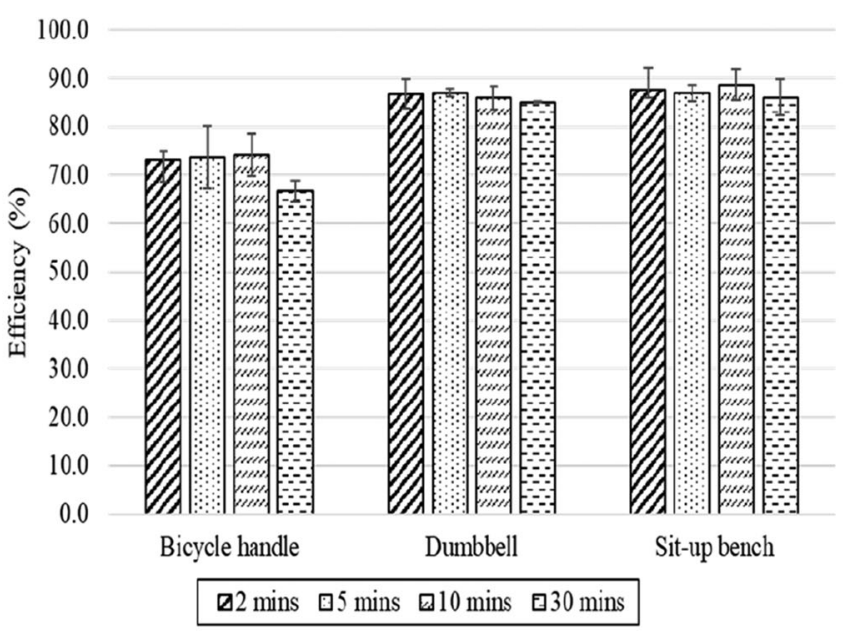

(b)

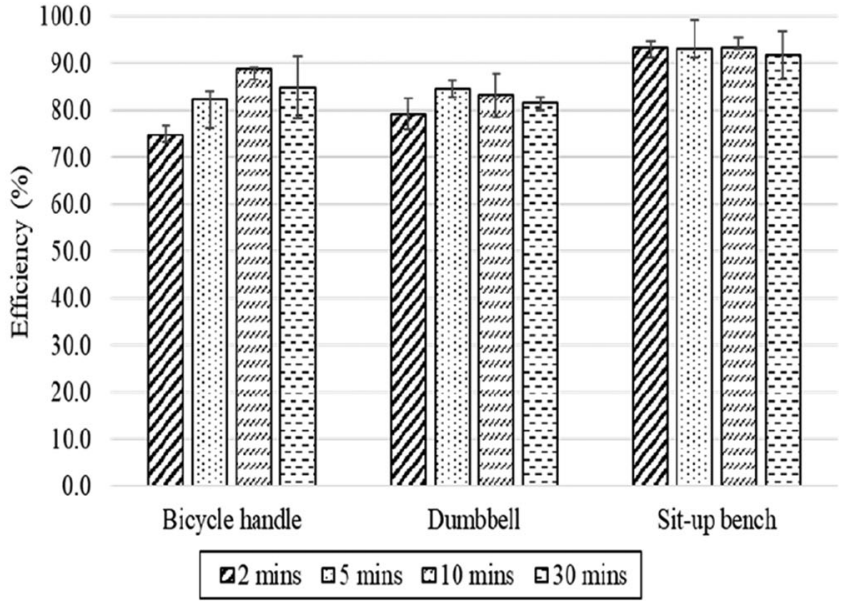

(d)

Fig. 4 Effectiveness of bacteria disinfection after cleaning by four disinfectants $(N=2)$. (a) Chlorine dioxide, (b) WAHW, (c) zinc oxide, and (d) commercial disinfectant

of $\mathrm{ZnO}$ nanoparticle aqueous solution in indoor environment may cause adverse health impact. $\mathrm{ZnO}$ nanoparticles remaining after water evaporation can be suspended by air movement and disperse in the air over a long period of time in the exercise room. Inhalation of these nanoparticles was found to cause lung inflammation and other negative effects in mice (Chen et al. 2015; Larsen et al. 2016).

Commercial disinfectant, which contains cetrimide and chlorhexidine digluconate, could inactivate bacteria and E. coli on sit-up bench better than bicycle handle and dumbbell as shown in Figs. 4(d) and 5(d). The commercial disinfectant seems to be suitable for the sports equipment which has smooth surface like sit-up bench rather than rough surface as in the case of bicycle handle and dumbbell.

In summary, all disinfectants could remove bacteria and E. coli immediately after application, although the highest disinfection efficiency occurred at different contact times. Nonetheless, it implies that users can use these equipment straight-away after disinfection without a long waiting period. Chlorine dioxide and $\mathrm{ZnO}$ had comparable inactivation effectiveness regardless of sports equipment and surface roughness as shown in Fig. 4(a) and (c), respectively. It is interesting to observe that WAHW and commercial disinfectant could disinfect total bacteria on the sit-up bench slightly better than handles of the bicycle and dumbbell which had rougher surface as shown in the Fig. 4(b) and (d), respectively. The results also demonstrated that the effectiveness of disinfectants somehow depends on the surface characteristics of sports equipment as well.

The $E$. coli disinfection of all disinfectants are quite comparable although the commercial disinfectant showed noticeable less effectiveness on the handles of the bicycle as shown in Fig. 5. Coupled with the findings from bioaerosol disinfection as reported earlier, $\mathrm{ClO}_{2}$ seems to be a better choice for sanitizing the sports equipment since it was also found to be highly efficient for bioaerosol disinfection as well. Although 


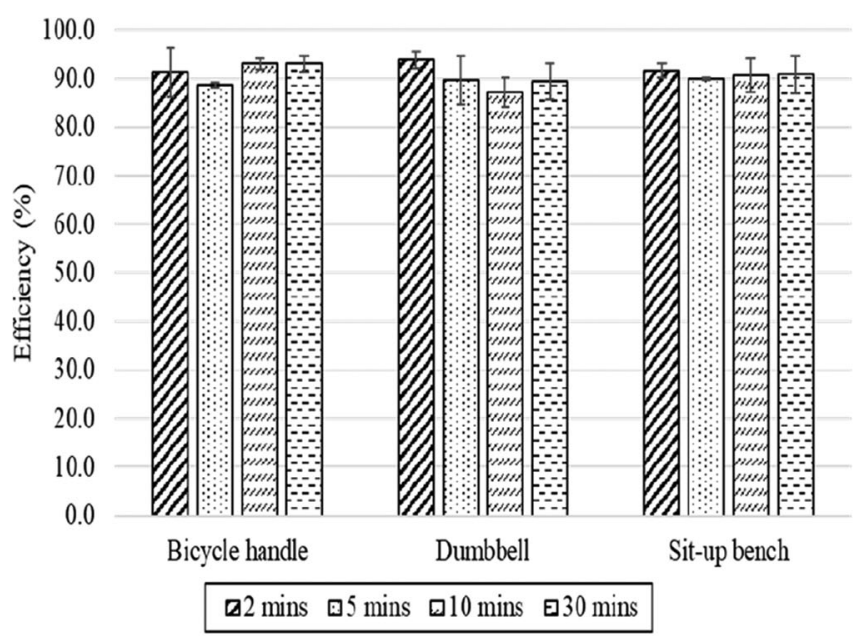

(a)

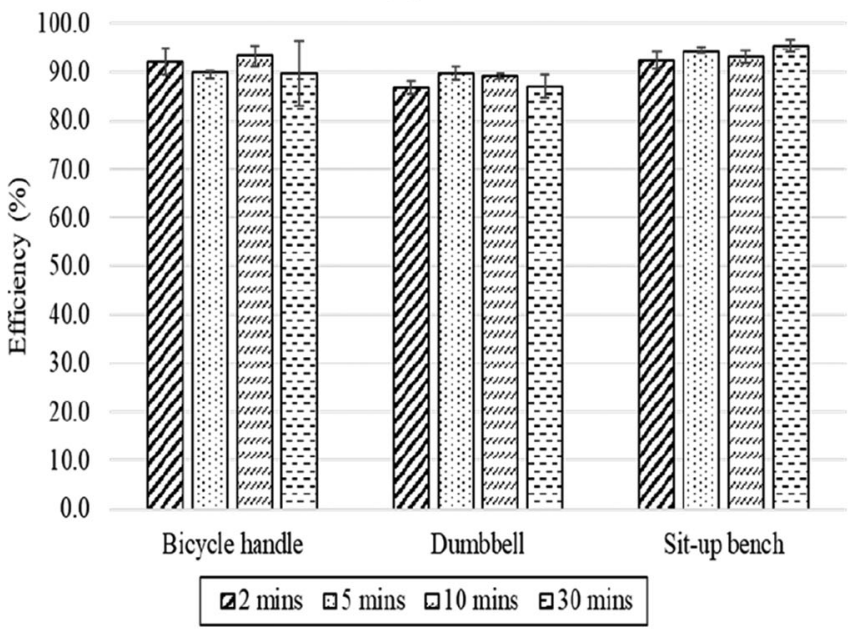

(c)

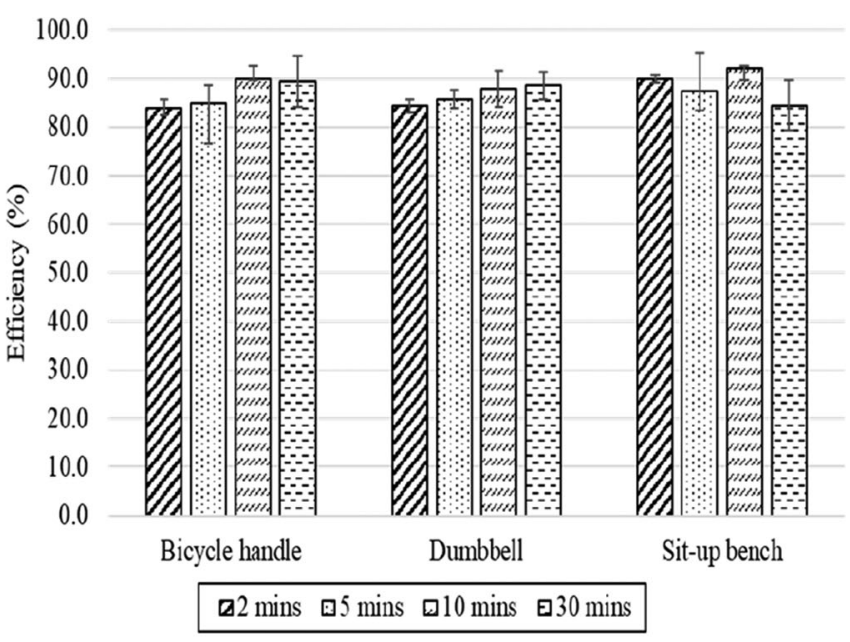

(b)

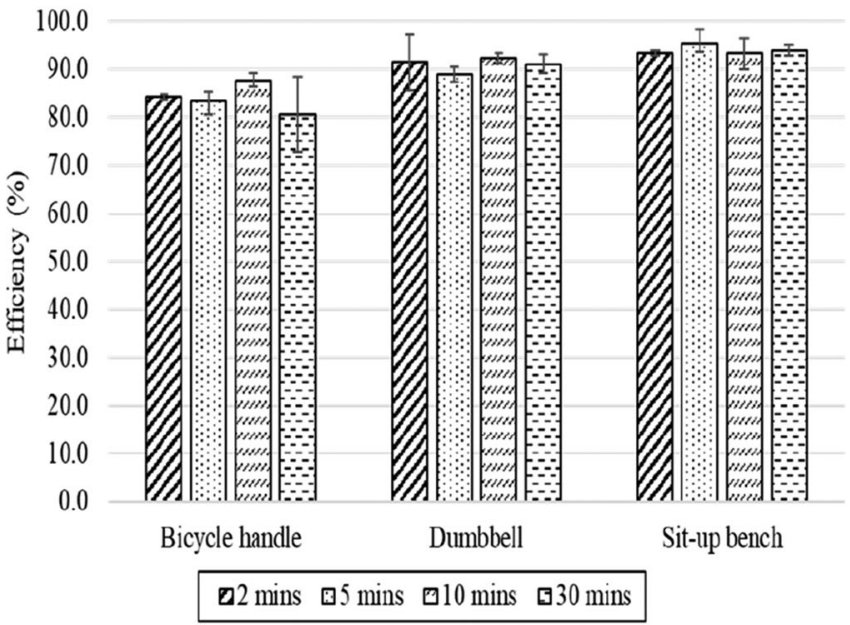

(d)

Fig. 5 Effectiveness of E. coli disinfection after cleaning by four disinfectants $(\mathrm{N}=2)$. (a) Chlorine dioxide, (b) WAHW, (c) zinc oxide, (d) commercial disinfectant

$\mathrm{ZnO}$ and commercial disinfectant were effective for surface disinfection, they are not appropriate nor recommended to apply aerially for bioaerosol disinfection since the former are nano-powders which can cause irritation and toxicity to the respiratory system whereas the latter is primarily produced for surface antiseptic.

It is important to note that this study was carried out during the time of COVID-19 pandemic; thus, the number of users drastically was reduced. According to Kalogerakis et al. (2005), the most important source of airborne bacteria is the presence of people who come to exercise. Particular activities like talking, sneezing, coughing, walking, washing, and toilet flushing can generate airborne biological particulate matter. Therefore, the initial concentrations of bacteria detected in this study were not as high as it should be under normal condition. Nonetheless, the effectiveness of each disinfectant on targeted microorganisms is still valid and can be further applied for normal condition with certain modifications.

\section{Conclusions}

This study investigated the effectiveness of bioaerosol disinfection in a fitness room after usage by using $\mathrm{ClO}_{2}$, WAHW, and water. Our results indicate that $\mathrm{ClO}_{2}$ was more effective on fungi inactivation whereas WAHW was better for bacteria disinfection. Water had the least efficiency in removing bioaerosols from the air as expected via physical scrubbing, not disinfection. Number of users statistically diminished the bacteria and fungi removal efficiencies during the experimental period of $60 \mathrm{~min}$ for all tested schemes. According to the outcomes, disinfecting the air in the fitness room by $\mathrm{ClO}_{2}$ aerosolization for $15 \mathrm{~min}$ after usage seems to be the most appropriate option for both bacteria and fungi control in bioaerosols in order to improve the air quality in the indoor environment and human health. For microorganisms on sports equipment control, it was found that $\mathrm{ClO}_{2}$ and $\mathrm{ZnO}$ were noticeably better disinfectants than WAHW and commercial 
disinfectant in terms of bacteria inactivation whereas all chemicals had comparable effectiveness on $E$. coli disinfection. Targeted microorganisms were effectively inactivated in 2 min after application. Concerning on overall disinfection performance of both bioaerosols and surface of sports equipment, $\mathrm{ClO}_{2}$ was found to be the most appropriate and effective disinfectant.

Availability of data and materials All data generated, used, and analyzed during this study are included in this article.

Author contribution MCL conceptualized and designed the study, secured the funding of the research, and planned the research activities. $\mathrm{He}$ is the corresponding author. NB contributed to the conceptualization and design of the study, supervised the implementation of the research activities, and mentored the other members of the research group. SY and FJL performed the experiments and data collection and initial analysis of the data, and prepared the initial draft of the manuscript. LMB performed some analysis of the data, reviewed, edited, and critically revised the manuscript. All authors read and approved the final manuscript for submission.

Funding This research was made possible through the funding grant by the Ministry of Science and Technology, Taiwan, MOST 107-2622-E041-002-CC3.

\section{Declarations}

Ethics approval and consent to participate Not applicable.

Consent for publication Not applicable.

Competing interests The authors declare no competing interests.

\section{References}

Block MS, Rowan BG (2020) Hypochlorous acid - a review. J Oral Maxillofac Surg 78(9):1461-1466. https://doi.org/10.1016/j.joms. 2020.06.029

Chen N-T, Su Y-M, Hsu N-Y, Wu P-C, Su H-J (2012) Airborne fungi and bacteria in child daycare centers and the effectiveness of weak acid hypochlorous water on controlling microbes. J Environ Monit 14(10):2692-2697. https://doi.org/10.1039/c2em30113j

Chen KK, Ho CC, Chang H, Lin JF, Yang CS, Tsai MH, Tsai HT, Lin P (2015) Particulate nature of inhaled zinc oxide nanoparticles determines systemic effects and mechanisms of pulmonary inflammation in mice. Nanotoxicology 9:43-53

Cho J-L, Kim C-K, Park J, Kim J (2017) Efficacy of aerosolized chlorine dioxide in reducing pathogenic bacteria on washed carrots. Food Sci Biotechnol 26(4):1129-1136

Dalman M, Bhatta S, Nagajothi N, Thapaliya D, Olson H, Naimi HM, Smith TC (2019) Characterizing the molecular epidemiology of Staphylococcus aureus across and within fitness facility types. BMC Infect Dis 19:69

Dimapilis EAS, Hsu CS, Mendoza RMO, Lu MC (2018) Zinc oxide nanoparticles for water disinfection. Sustain Environ Res 28:47-56

Environmental Protection Administration R.O.C. (Taiwan) (2014) Progress in indoor air quality control. Environ Policy Mon 17(7): $1-12$
Garcia-Avila F, Aviles-Anazco A, Ordonez-Jara J, Guanuchi-Qyezada C, Flores del Pino L, Ramos-Fernandez L (2021) Modeling of residual chlorine in a drinking water network in times of pandemic of the SARS-CoV-2 (COVID-19). Sustain Environ Res 31:12

Hsu CH, Lu MC, Huang DJ (2014) Effect of gaseous chlorine dioxide on student cafeteria bioaerosols. Clean Soil Air Water 42(1):12-19

Hsu CH, Lu MC, Huang DJ (2015) Disinfection of indoor air microorganisms in stack room of university library using gaseous chlorine dioxide. Environ Monit Assess 187:17

Ishihara M, Murakami K, Fukuda K, Nakamura S, Kuwabara M, Hattori H, Fujita M, Kiyosawa T, Yokoe H (2017) Stability of weakly acidic acid solution with microbicidal activity. Biocontrol Sci 22(4):223227

Jaemsri P, Rujak K (2017) Verification of plate count agar (PCA) and Reasoner's 2A (R2A) agar for enumeration of heterotrophic bacteria in water and ice. Bull Dept Med Sci 59(4):242-251

Kalogerakis N, Paschali D, Lekaditis V, Pantidou A, Eleftheriadis K, Lazaridis M (2005) Indoor air quality-bioaerosol measurements in domestic and office premises. Aerosol Sci 36:751-761

Larsen ST, Jackson P, Poulsen SS, Levin M, Jensen KA, Wallin H, Nielsen GD, Koponen IK (2016) Airway irritation, inflammation, and toxicity in mice following inhalation of metal oxide nanoparticles. Nanotoxicology 10:1254-1262

Lenntech B. V (2020) Disinfectants chlorine dioxide. Available online: https://www.lenntech.com/processes/disinfection/chemical/ disinfectants-chlorine-dioxide.htm. Accessed on 5 April 2020

Lu MC, Huang DJ, Hsu CH, Liang CK, Chen GM (2018) Improvement of indoor air quality in pet shop using gaseous chlorine dioxide. Environ Monit Assess 190:371

Markley JD, Edmond MB, Major Y, Bearman G, Stevens MP (2012) Are gym surfaces reservoirs for Staphylococcus aureus? A point prevalence survey. Am J Infect Control 40:1008-1009

Mcdonnell G, Russell AD (1999) Antiseptics and disinfectants: activity, action, and resistance. Clin Microbiol Rev 12(1):147-179

Mukherjee N, Sulaiman IM, Banerjee P (2016) Characterization of methicillin-resistant Staphylococcus aureus isolated from fitness centers in the Memphis metropolitan area, Tennessee. Am J Infect Control 44:1681-1683

Nguyen K, Bui D, Hashemi M, Hocking DM, Mendis P, Strugnell RA, Shyamali C, Dharmage SC (2021) The potential use of hypochlorous acid and a smart prefabricated sanitising chamber to reduce occupation-related COVID-19 exposure. Risk Manag Health Care Policy 14:247-252

OSHA (2020) Permissible Exposure Limits. Available online: https:// www.osha.gov/dsg/annotated-pels/tablez-1.html\#calosca pel. Accessed on 11 April 2020

Quan Y, Kim H-Y, Shin I-S (2017) Bactericidal activity of strong acidic hypochlorous water against Escherichia coli O157:H7 and Listeria monocytogenes in biofilms attached to stainless steel. Food Sci Biotechnol 26(3):841-846

Rajasekar A, Balasubramanian R (2011) Assessment of airborne bacteria and fungi in food courts. Build Environ 46:2081-2087

Ramos CA, Wolterbeek HT, Almeida SM (2014) Exposure to indoor air pollutants during physical activity in fitness centers. Build Environ $82: 349-360$

Ramos CA, Reis JF, Almeida T, Alves F, Wolterbeek HT, Almeida SM (2015) Estimating the inhaled dose of pollutants during indoor physical activity. Sci Total Environ 527-528:111-118

Rutala WA, Weber DJ (1997) Uses of inorganic hypochlorite (bleach) in health-care facilities. Clin Microbiol Rev 10(4):597-610

Ryan KA, Ifantides C, Bucciarelli C, Saliba H, Tuli S, Black E, Thompson LA (2011) Are gymnasium equipment surfaces a source of staphylococcal infections in the community? Am J Infect Control 39:148-150 
Saini J, Dutta M, Marques G (2020) A comprehensive review on indoor air quality monitoring systems for enhanced public health. Sustain Environ Res 30:6

Sirelkhatim A, Mahmud S, Seeni A, Kaus NHM, Ann LC, Bakhori SKM, Hasan H, Mohamad D (2015) Review on zinc oxide nanoparticles: antibacterial activity and toxicity mechanism. Nanomicro Lett 7(3): 219-242

Taiwan EPA (2016a) Guidelines on indoor air quality, Taiwan Environmental Protection Administration. online: https://www.epa. gov.tw/niea/25CCBDCE257C40E4. Accessed on 3 March 2020

Taiwan EPA (2016b) Guidelines on indoor air quality, Taiwan Environmental Protection Administration. Available online: https://www.epa.gov.tw/niea/E13AE1B6E1D2F256. Accessed on 3 March 2020
Tsai MY, Liu HM (2009) Exposure to culturable airborne bioaerosols during noodle manufacturing in Central Taiwan. Sci Total Environ 407:1536-1546

World Health Organization (WHO) (2018) Physical activity on 23 February 2018. Available online: https://www.who.int/newsroom/fact-sheets/detail/physical-activity. Accessed on 30 March 2020

Zhu H, Phelan P, Duan T, Raupp G, Fernando HJS (2003) Characterizations and relationship between outdoor and indoor bioaerosols in an office building. China Particuol 1(3):119-123

Publisher's note Springer Nature remains neutral with regard to jurisdictional claims in published maps and institutional affiliations. 